\title{
Implementation of the National Health Insurance Referral System at the Public Health Center in the Pangkajene Kepulauan District in 2019
}

\author{
Nurul Fajriah Istiqamah ${ }^{1}$, Darmawansyah Darmawansyah ${ }^{1 *}$, Muhammad Syafar $^{2}$, Anwar Mallongi $^{3}$ \\ ${ }^{1}$ Department of Health Administration and Policy, Public Health of Faculty, Hasanuddin University, Makassar, Indonesia; \\ ${ }^{2}$ Department of Health Promotion and Behavioral Sciences, Public Health of Faculty, Hasanuddin University, Makassar, \\ Indonesia; ${ }^{3}$ Department of Environmental Health, Public Health of Faculty, Hasanuddin University, Makassar, Indonesia
}

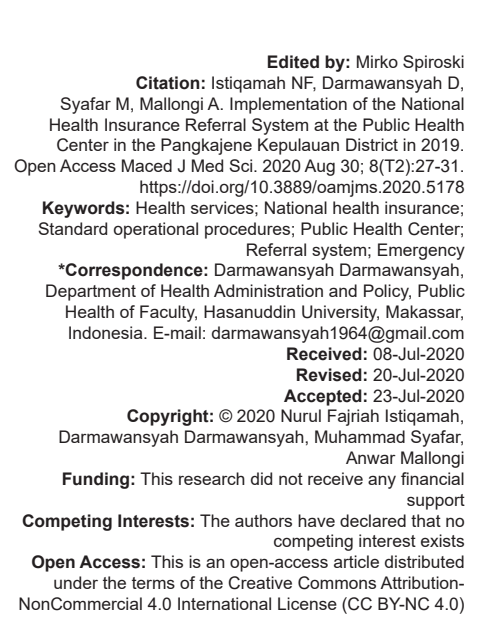

\section{Abstract}

BACKGROUND: The health service referral system is the organization of health services that regulate the mutua assignment of tasks and responsibilities of health services both vertically and horizontally.

AIM: The purpose of this study was to determine the appropriateness of referral service operational standards at the Kalabbirang Public Health Center in Pangkajene Kepulauan district.

METOHDS: This research method uses a qualitative with a phenomenological. The location of this study is in the Kalabbirang Public Health Center. The informants in this study were the Head of Medical Records Installation the medical records installation staff of registration, doctors, and nurses. Data collection techniques using in-depth interviews, document review, and observation. The data obtained analyzed using the content analyze.

RESULTS: The results showed that the Kalabbirang Public Health Center, no operational service standards were governing the procedures of the Public Health Center when receiving patients to be referred back. In addition, doctors do not explain in full to patients information about the referral. The conclusion of this research is the implementation of the referral system at the Kalabbirang Public Health Center in terms of the requirements for referring to be in accordance with the national referral system

CONCLUSION: We need socialization to understand more deeply about the referral system and equate perceptions among health workers about the referral mechanism in the Kalabbirang Public Health Center.

\section{Introduction}

The Public Health Center is a health service facility that organizes public health efforts and firstlevel individual health efforts, with more emphasis on promoting and preventive efforts, to achieve the highest degree of public health [1]. To improve the degree of public health and support the success of national social security, Public Health Center needs to be reorganized to improve accessibility, affordability of health facilities, and quality of health services.

The first-level health facilities as gatekeepers in the era of national health insurance are required to provide comprehensive primary services with quality health services [2]. Hence, the first-level health facilities are expected to be an excellent health service facility. To support these services, financing through the capitation system is strongly supported by the government. Capitation is a financing system that is calculated based on the number of national health insurance membership in first-level health facilities [3]. The tiered referral system is an effort to increase cooperation between health facilities.

The health service referral system is the organization of health services that regulate the mutual assignment of tasks and responsibilities of health services both vertically and horizontally. Vertical referral is a referral between health services of different levels which can be done from lower service levels to higher service levels or vice versa while horizontal referral is a referral between health services in one level, carried out if the referrer cannot provide health services according to patient needs due to limited facilities, equipment [4], [5].

Based on data from health insurance, the number of first-level outpatient visits is the number of participants who examine first-level health facilities. The number of visits first-level outpatient in 2017 reached $150,288,478$ visits or an increase of $24.29 \%$ when compared to the realization in $2016(120,922,433$ visits). The number of referrals from first-level health facilities nationally in 2017 reached 18,891,657 referrals, with a referral ratio of $12.56 \%$ and an average 
number of referrals per month of $1,574,305$ references (BPJS, 2017). The percentage of referral exceeds the target of safe zone indicators based on health insurance regulation No. 2 of 2015, namely, <5\% [6].

Based on data obtained from the Pangkajene Kepulauan District Health Office in 2017, the total number of national health insurance participant referrals in all Public Health Center in Pangkajene Kepulauan District who were referred to advanced referral health facilities in 2017 was 19,789 (9.5\%) referral cases, whereas in 2018, the number overall national health insurance participant referrals in all Public Health Center in Pangkajene Kepulauan District who were referred to Advanced Referral Health Facilities increased by 36,406 $(15.3 \%)$ referral cases. The number of referral cases in Pangkajene Kepulauan District exceeds the indicator target set by health insurance. Factors that cause a high ratio of referral rates are the incompatibility of drugs with the needs that exist in the health center, the continued high treatment for chronic diseases [7], [8].

Therefore, it is necessary to assess the quality of referrals to see whether the patients referred are following the operational service standards and see aspects of the completeness and accuracy of the referral. The increase in the number of referrals in first-level health facilities companied by the low quality of referrals will result in inefficiency and result in losses by health insurance. This study aims to explore in-depth information from informants regarding the implementation of the national referral system at the Kalabbirang Public Health Center.

\section{Materials and Methods}

This research was conducted at the Kalabbirang Public Health Center, Pangkajene Kepulauan District of South Sulawesi Province in the August-September 2019 period. The type of research was qualitative with a phenomenological approach. The focus of this research is on the role and experience of informants in implementing the referral system.

The informants in this study were determined by the principle of suitability and adequacy. The technique of taking informants in this study is purposive sampling technique. Determination of the initial informant will begin with the head of the medical records installation, then the next informant is the medical records installation staff, registration, doctors, and nurses as well as patients.

Data collection is done by extracting data from various techniques and sources to clarify information in the field. The data obtained are primary. These primary data were obtained by in-depth interviews, observation, and document review.

Data obtained from the results of interviews with informants were further analyzed by content analysis methods. Content analysis is a technique used to analyze and understand the contents of information.

\section{Results}

The focus of this research is the process component in the systems approach theory, because this study wants to see how the implementation of a program that is the referral system program at the Public Health Center. What is included in the process component in this research is the suitability of the existing operational service standards at the Kalabbirang Health Center to Permenkes No. 001 of 2012 concerning the referral system.

In this study, what is meant by conformity to the operational standard of referral system services is that the health workers in the Kalabbirang Health Center in carrying out referrals are based on the operational standards of referral system implementation. In this study, it is known from the results of in-depth interviews and document review that the Public Health Center already has a referral operational service standards. This operational service standard is intended as a reference in referring patients from the health center to the hospital. In this operational service standards, two work procedures have been arranged, namely, if the patient is referred vertically and if the patient requests the referral himself. From the document review, the researcher is of the opinion that this operational service standard does not yet represent all activities in the national health insurance system, the operational service standards of the Kalabbirang Health Center only regulate how to refer patients to the hospital and procedures to refer patients at their own request, there are no procedures from the Public Health Center itself when receiving patients refer back.

From the results of in-depth interviews on Table 1, information was obtained from several informants who said that the referral operational service standards were found in various Kalabbirang Health Center.

Unlike the two informants said that a referral operational service standards for the internal Kalabbirang Public Health Center were to be made. From the results of in-depth interviews with patients, there are some patients who claim to have asked for their own referrals on the grounds that the disease does not heal with treatment and medication given at the Kalabbirang Health Center. From the results of in-depth interviews, it is known that the reason why referral cases at the Kalabbirang Health Center in 2018 were that the highest was due to the process of referral action. Many patients turned out that their health facilities were not at the Kalabbirang Health Center but because the distance between their homes to the Kalabbirang Health Center was closer to the health facilities. It is written on the health insurance card and therefore patients prefer 
Table 1: Analysis of referral system in Public Health Center Kalabbirang according to guidance system reference national, 2019

\begin{tabular}{|c|c|c|c|}
\hline No. & National referral system guidelines & Implementation at the Public Health Center & Study it \\
\hline \multicolumn{4}{|c|}{$\begin{array}{l}\text { Managing referrals from first-level to second-level health facilities } \\
\qquad \text { A. Terms refer }\end{array}$} \\
\hline 1 & $\begin{array}{l}\text { The patient to be referred has been examined and it is stated that the patient's } \\
\text { condition can meet the requirements for referral, vital signs are in good condition/ } \\
\text { stable and transportable and meet one of the conditions for referral }\end{array}$ & $\begin{array}{l}\text { At PHC, Kalabbirang implementation of the referral system has been } \\
\text { qualified for referral of patients, but some cases of patients ask their } \\
\text { referrals and also some of the patients treated at health centers } \\
\text { Kalabbirang listed on health facility other }\end{array}$ & Corresponding \\
\hline \multicolumn{4}{|c|}{ B. Standard procedures refer patients } \\
\hline 1 & $\begin{array}{l}\text { (a) Referral clinical procedures: } \\
\text { Clinical procedures in cases of no emergency referral processes follow the } \\
\text { established routine procedures, namely, providing health care to receive patients } \\
\text { at the Public Health Center, conducting, anamnesis, physical examination, and } \\
\text { medical support examinations that can be done by the Public Health Center to }\end{array}$ & $\begin{array}{l}\text { At the Kalabbirang Public Health Center, the referral system } \\
\text { implementation in carrying out clinical procedures has been by } \\
\text { established routine procedures, but the Kalabbirang Public Health } \\
\text { Center does not yet have an operational service standards regarding no } \\
\text { emergency case referrals }\end{array}$ & Corresponding \\
\hline
\end{tabular}

(b) Patients who come in a state of emergency and need medical emergency assistance, the authorized officer immediately conducts immediate assistance (life-saving procedures) to stabilize the patient's condition according to the operational service standards

(c) Concludes the case that the patient meets the requirements for referral, according to one of the criteria in the patient's referral requirements

(d) Preparing referrals for patients by giving patients and/or their families an explanation in a language understood by the patient/family, and informed consent as part of operational procedures that are very closely related to the technical procedures of patient care must be carried out

(e) Explanation related to the disease/patient's health problems and the patient's current condition, the purpose, and importance of the patient must be referred, where the patient will be referred, the consequences or risks that occur if the referral is not made, and the benefits of referral

(f) Plans are made and the process of implementing referrals as well as possible actions to be taken in the referral health facilities to be addressed

(g) Explained the things that need to be prepared by the patient/family

(h) Other explanations relating to the referral process including various complete requirements to give patients/family opportunities

(i) The final decision on the referral implementation plan is on the patient and or his family to agree or refuse to be referred according to the existing referral flow, as well as the final agreement or the results of the explanation stated by signing the two parties in the format of informed consent according to the procedure

(j) The approval of the referral of the patient/family, health center is authorized to prepare a referral by providing measures pre-referral suit the patient's condition before referral by operational service standards

(k) Public Health Center call back service units in health facility referral destinations, to ensure once again that the patient can be accepted in health facility referral or have to wait a while or find health facility other reference as an alternative

Kalabbirang Public Health Center operational service standards corresponding regulates the stabilization of emergency patient conditions to be referred

Conclusion of cases that patients meet the requirements for referral has been carried out by the Kalabbirang Public Health Center Kalabbirang Public Health Center has provided the patient or family with a clear explanation and also provided an informed consent sheet to the patient

Kalabbirang Public Health Center only provides an explanation of the results of the patient's diagnosis, the importance of the patient must be referred, but does not explain in full about where the patient will be referred, the consequences or risks that occur if the referral is not done and the benefits are made referral

Kalabbirang Public Health Center has carried out plans and the process of implementing referrals as well as possible actions to be taken at the referral health facilities to be addressed

Kalabbirang Public Health Center has explained to patients what things must be prepared

Kalabbirang Public Health Center provides explanations as needed to the patient's family as well as his patients

Implementation of informed consent has been carried out by the Kalabbirang Public Health Center, by signing the two patients/families with medical personnel in an informed consent format according to the procedure

Kalabbirang Public Health Center has asked permission from the patien or the patient's family to prepare the action before referral

The Kalabbirang Public Health Center not call back health facility referral destinations to ensure once again that the patient can be accepted in health facility referral destinations or have to wait a while or find health facility other reference as an alternative

(a) Done in line with the technical procedures of the patient
(b) Completing the patient's medical record, after the action to stabilize the patient's
pre-referral condition
ation procedures

The Kalabbirang Public Health Center carries out administrative procedures by technical procedures on patients

The Kalabbirang Public Health Center has completed the patient's medical record to be referred as well as stabilization measures, completeness in the form of a patient diagnosis, diagnosis code, and Poli and hospital to be referred for referral The Kalabbirang Public Health Center has completed informed consent according to the format of the procedure for the signatures of both parties, the Public Health Center and the patient/family if the final decision agrees or does not agree to be referred

decision agrees or does not agree to be referred
The Kalabbirang Public Health Center has kept an informed consent format that has been signed and is stored in the patient's medical record but has not used ICT/ICT decision has been taken to agree or refuse to be referred, it must still cor informed consent according to the format of the procedure for the signatures of both parties, the Public Health Center and the patient/family

(d) Furthermore, the informed consent format that has been signed is stored in the patient's medical record, if an ICT/ICT device has been used the informed consent format can be supplemented with photos, recordings of the decisionmaking process talks, and others

(e) Furthermore, if the patient has agreed to be referred, then PHC must make a referral of patients in 2, the first copy was sent to health facility referral with the patient, the second sheet is stored as a record shared medical records of patients who will be referred

(f) Public Health Center must record patients in the patient's referral register

(g) Administration of sending patients must be completed when the patient will be

The Kalabbirang Public Health Center has made a duplicate patient referral letter, the first sheet is sent to the referral health facility with the patient, the second sheet is kept as an archive with the patient's medical record to be referred

The Kalabbirang Public Health Center does not have a special book for referral cases referred immediately

Administration of patient delivery has been completed when the patient will be referred immediately

(1)

\section{.}


Health Center already has a referral operational service standard. This operational service standard is intended as a reference in referring patients from the health center to the hospital. In this operational service standard, two work procedures have been arranged, namely, if the patient is referred vertically and if the patient requests a referral himself. Operational service standards at the Kalabbirang Health Center are incomplete because there are no operational service standards for emergency patients.

The implementation of the referral system in Indonesia has been arranged in a tiered or tiered form, namely, first, second, and third level health services, which in its implementation are not independent but are in a system and are interconnected. If the primary health service cannot perform primary level medical treatment, he/she surrenders the responsibility to the level of service above it and so on [9]. Similarly, research conducted by Vendetti et al. [10] in Cambodia said that most health centers $(60 \%)$ had contacted referral hospitals before transferring patients while other health centers (40\%) did not contact higher facilities before transferring patients. However, only $21 \%$ of facilities from the health center always contact the hospital when referring patients [10].

In this operational service standard, two work procedures have been arranged, namely, if the patient is referred vertically and if the patient requests the referral himself. This study is in line with research who said that the Sarolangun Health Center, Sarolangun District, Jambi Province, operational service standards of a referral system was available and its contents were only rules for referring to other Public Health Center [11] which means that for the referral process to another Public Health Center or to the hospital already exists but for the rules or operational service standards to receive a back referral does not yet exist [12]. Research demands that patients want a referral because they lack trust in health services at the first level of health facilities so that even though it is explained repeatedly that the disease can be treated at the Public Health Center but insists on continuing to ask for a referral by threatening to leave the Public Health Center [13]. Similar to the research which said that in the Siko Community Health Center, the operational service standards about the referral system is not yet complete, the contents of which are the patient service flow operational service standards, the process of referring patients from the health center to the hospital as referrers, while the operational service standards in receiving referrals forth are not yet available [14].

Based on Table 1, the implementation of the referral system at the Kalabbirang Health Center which is not appropriate, namely, the explanation relating to the patient's illness/health problem and the patient's current condition, the purpose and importance of the patient must be referred, where the patient will be referred, the consequences or risks that occur if the referral is not carried out, and the benefits of doing referrals and also the Public Health Center not contacting the destination health facilities again.
The reason why the Public Health Center does not fully inform patients about patients will be referred to where because in the Pangkajene Regency, there is only one regional hospital, Pangkep Regional Hospital, so although not informed the patient will understand where he will be referred to, to inform about the advantages and disadvantages of the referral to the patient not done in the Kalabbirang Community Health Center because according to informants, important information is only information on the results of the diagnosis and then gives a referral approval letter to the patient. In accordance with research that says that in Sarolangun Public Health Center, the explanation that should have been explained by the doctor was not explained in full [15].

The implementation of the referral system at the Kalabbirang Community Health Center which is not yet compatible with the second is the Public Health Center not to contact the hospital or health facility for the referral destination after the patient completes all administration before referral, the reason being that there are many patients so that the patient does not have the time to reconfirm the referral hospital. This study is in line with research it is known that the Tambakrejo Health Center and the Kali Kedinding, Surabaya, before making a labor referral contact the destination hospital first and submit a case that will be referred to guarantee the availability of a place in the hospital and not confirm repeated when the patient has completed all forms of administration because it has been previously confirmed [16], [17], [18], [19].

\section{Conclusion}

Based on the findings and conclusions of the need for socialization to be able to understand more deeply about the referral system and equate perceptions among health workers about the referral mechanism in the Kalabbirang Public Health Center.

\section{Recommendation}

Suggestions in this study are based on the findings and conclusions of the need for socialization to be able to understand more deeply about the referral system and equate perceptions among health workers about the referral mechanism at the Kalabbirang Public Health Center. 


\section{References}

1. Kemenkes RI. Peraturan Kementerian Kesehatan Republik Indonesia Nomor 28 Tahun 2014 Tentang Pedoman Pelaksanaan Program Jaminan Kesehatan Nasional. Jakarta: Menteri Kesehatan; 2014. https://doi.org/10.20884/1.jih.2018.4.2.115

2. Ratnasari D. Analisis pelaksanaan sistem rujukan berjenjang bagi peserta national health insurance di puskesmas $X$ Kota Surabaya. J Adm Kesehatan Indones. 2018;5(2):145-54. https:// doi.org/10.20473/jaki.v5i2.2017.145-154

3. Febriawati $H$, Yandrizal $Y$, Afriza $Y$, Pratiwi BA, Yanuarti $R$, Suryani D. Analisis besaran dan pembayaran kapitasi berbasis komitmen pelayanan terhadap pengendalian rujukan di public health center Kota Bengkulu. J Kebijakan Kesehatan Indones. 2017;6(2):204-9.

4. Marina E, Setiawati, Rahmah HN. Evaluasi pelaksanaan sistem rujukan berjenjang dalam program jaminan kesehatan nasional. J Kebijakan Kesehatan Indones. 2019;8(1):35-40. https://doi. org/10.33485/jiik-wk.v5i2.129

5. Kemenkes RI. Peraturan Kementerian Kesehatan Republik Indonesia Nomor 001 Tahun 2012 Tentang Sistem Rujukan Pelayanan Kesehatan Perorangan. Jakarta: Menteri Kesehatan; 2012. https://doi.org/10.20884/1.jih.2018.4.2.115

6. BPJS Kesehatan. Peraturan Badan Penyelenggara Jaminan Sosial Kesehatan Nomor 8 Tahun 2016 Tentang Penerapan Kendali Mutu Dan Kendali Biaya Pada Penyelenggaraan Program Jaminan Kesehatan Nasional. Jakarta: BPJS Kesehatan; 2016. https://doi.org/10.33603/hermeneutika. v4i1.3275

7. Ambarwati D, Pangesti WD, Dewi S. Pelaksanaan sistem rujukan pada kasus kegawatdaruratan maternal neonatal di puskesmas Kembaran I. Bidan Prada. J Publ Kebidanan Akbid YLPP Purwokerto. 2018;9(2):132-56.

8. Woro I, Endartiwi SS. Pelaksanaan kebijakan rujukan berjenjang bagi peserta BPJS kesehatan. J IImiah IImu Kesehatan. 2019;5(2):196-204. https://doi.org/10.33485/jiik-wk.v5i2.129

9. Aziz M. Sistem rujukan pasien badan penyelenggara sosial (BPJS) kesehatan (studi kasus di puskesmas Umbulharjo I Yogyakarta). J Kesehatan. 2015;2(1):165-265. https://doi. org/10.31850/makes.v1i3.106
10. Vendetti J, Gmyrek A, Damon D, Singh M, Mcree B, Del Boca F. Screening, brief intervention and referral to treatment (SBIRT): Implementation barriers, facilitators and model migration. Addiction. 2017;112(21):23-33. https://doi.org/10.1111/ add.13652 PMid:28074571

11. Mustainnah. Analisis sistem rujukan berdasarkan standar oprasional pelayanan di public health center Sarulangun. J Kesehatan. 2017;2(1):254-354.

12. Lestary $H$, Sugiharti $S$, Mujiati M. Sistem rujukan maternal dan neonatal di daerah kepulauan (studi kasus di Provinsi Papua dan Maluku). Med Penelitian dan Pengembangan Kesehatan. 2018;28(3):83-94. https://doi.org/10.22435/mpk.v28i2.177

13. Goniwala G. Gambaran pelaksanaan rujukan peserta BPJS kesehatan di public health center tikala baru dan public health center teling atas di Kota Manado. J Kesehatan. 2017;1(2):5766. https://doi.org/10.37148/arteri.v1i3.103

14. Amirul D, Mustofa A. Analisis kebijakan regionalisasi rujukan terhadap jumlah kunjungan dan kepuasan peserta jaminan kesehatan nasional di faskes rujukan tingkat lanjutan. J Health Stud. 2017;11(2):267-7. https://doi.org/10.31101/jhes.338

15. Kesumawati NI. Analisis sistem rujukan berdasarkan standar oprasional pelayanan di public health center Sarulangun. J Kesehatan. 2012;3(1):135-41.

16. Rukmini R. Pelaksanaan sistem rujukan maternal di public health center tambakrejo dan tanah kali kedinding Kota Surabaya. Bul Penelitian Sist Kesehatan. 2015;18(2):365-75. https://doi.org/10.22435/hsr.v18i4.4570.365-375

17. Syam A, Sari NP, Thaha AR, Suriah, Jafar N, Salam A, et al. The effect of pumpkin seed flour (Cucurbita moschata Durch) on zinc serum levels in malnourished Wistar rats. Enferm Clin. 2020;30(4):337-40. https://doi.org/10.1016/j.enfcli.2019.10.095

18. Palutturi S, Rutherford S, Davey P, Chu C. Comparison between healthy cities and Adipura in Indonesia. Malays $\mathrm{J}$ Med Health Sci. 2013;9(1):35-43.

19. Darmawansyah, Said M, Yunus R, Palutturi S. Increasing inpatient service quality of using quality function deployment method in Nene Mallomo hospital of sidrap regency, Indonesia. Indian J Public Health Res Dev. 2018;9(4):287-91 https://doi. org/10.5958/0976-5506.2018.00299.1 